\title{
Application of Regional Music Culture in College Music Teaching
}

\author{
Qingxun Li \\ School of Music \\ Huanghe Science and Technology College \\ Zhengzhou, Henan, China 450000
}

\begin{abstract}
Regional music culture is important content of college music teaching system as well as cultural symbol in ethnic minority areas of our country. Regional music represents humanistic characteristics and cultural history of various regions. The development of it also receives extensive attention of the society. With development of cultural diversity, dissemination and promotion of regional music culture has become modern characteristics of hierarchical development of society. It becomes research hotspot of teachers and art workers about how to improve the inheritance and development of regional music culture through college music teaching. This article discusses regional music culture, starts from values of regional music culture on college music and puts forward suggestions for college music teaching through analysis on research-oriented learning strategy, in order to provide reference basis for teaching level of regional music culture in universities.
\end{abstract}

Keywords-regional music culture; college music; teaching

\section{INTRODUCTION}

Regional music culture is outspread cultural branch that takes specific region and natural environment as main carriers and becomes a relatively stable distinctive culture through long-run development and enriches continuously with modern development. Regional music culture includes main forms of an area such as nature, geography and humanity; meanwhile, it also shows characteristics of the whole area in all ages. It becomes important hot subjects of music research field about how to inherit and popularize regional music culture in the process of modern development [1-3]. This article mainly chooses regional music culture in college music to research, provides reference basis for inheritance and development of regional music through analyzing its value, teaching model and concrete practice, looking forward to sharing and discussing with teachers and scholars.

\section{Analysis on Value of Regional Music CUlture iN College Music}

College music is a basic course of music major and includes many branches of music discipline; the teaching universality of college music mainly embodies on public elective course. Its main purpose is to use music education mechanism to carry out aesthetic education on non-music major students, in order to convey the beauty of music art as well as improve comprehensive quality of college students.
Regional music culture is very important element in teaching materials of college music, mainly including patterns of manifestation such as "appreciating folk songs" and "appreciating ethnic orchestral music". Teaching materials of college music also tell national instrumental music and traditional opera in various regions and show important influence and status of regional music culture [4-7]. However, in terms of specific practical experience of college music teaching, regional music teaching often cannot get the favor of most students; it is because students lack understanding for traditional culture and teachers' teaching model has corrupt practice. With fast development of pop music culture, students pay more attention to burgeoning music mode. It becomes priority subject of regional music culture teaching at the present stage about how teachers can reasonably implement macroeconomic regulatory on this phenomenon to ensure the value of traditional culture and carry out student-centered teaching activities.

\section{Promoting EfFect of InVestigative Study Method on Regional Music Culture}

Investigative study refers to student-oriented teaching activity with teachers' guidance. It mainly aims at stimulating students' interest in learning through research mode and then achieves freer, more effective and innovative teaching effects. The investigative study method in regional music culture requires teachers to guide students to choose research topics conforming to their interests and rules of music development in the process of understanding nature, society or life, learn in the form of individual or group, let students truly participate in study research and obtain learning experience through personal experience. Investigative study plays a significant effect on mobilizing students' learning enthusiasm. Looking from characteristics of students' cognitive structure at the present stage, most students know little about traditional culture and have no interests in learning traditional music culture class organized by schools, then it leads to the situation that the teaching effect of music class is not good. Regional music culture has natural classification attribute. For college students with diversified interests from all corners of the country, it has advantage of investigative study with sky-high integrating degree. Teachers shall make full use of these characteristics to teach and design, arouse students' interests in regional music culture on the basis of their own regional culture, to lay foundation for effective development of teaching. 


\section{How to PROMOte DeVElopMent OF REgional Music Culture IN COLLEGE MusiC}

\section{A. Reasonably Set Courses to Embody Contents of Inheritance}

Curriculum provision is important content of regional music culture of college music. It standardizes main scope and path for students to accept music education and has dominant function. In terms of requirements of modern music education, the curriculum provision of regional music culture shall develop towards openness and practicality and add course of special topic and miniaturized courses and ensure timeliness and flexibility of courses, create brand course group depending on college and characteristics of regional music culture and lay wide platform for students to understand and perceive regional music culture. [8]

Except for harvesting resources from traditional classroom and books, open courses shall fully excavate richer curriculum resources in school, family and social life. Classroom teaching extends to community, museum, mass art centers, field and social folk activities. Secondly, the practicality of music course strives to change the teaching status that pays attention to theory and thinks little of utility and attach importance to combination of professional knowledge and industry application and guiding students to learn outspread knowledge. Improve practical level of regional music culture in colleges through set activities such as student concert, artistic practice in and outside school, research on regional music life and environmental music. Besides, the special topic development of regional music culture course tries to surpass the curriculum view that centers on disciplinary knowledge. The course contents are carried out in screw type and form complete course group; these courses include collecting folk songs under the leadership of teachers, training dialect singing, special lecture, instruction on introduction, comprehensive performance and guidance on edit and creation, not only respecting students' requirements for individualized development, but also laying solid foundation for promotion of teaching quality level. The establishment of miniaturized courses bases on current situation and requirements of practical teaching of local universities. This kind of courses brings some burgeoning music phenomenon in society into research category of regional music and practical teaching contents, such as researches on transition of square dance, Huadeng opera and flower drum opera in cities. The setting of regional characteristic course freeze-frames and changes abstract regional music culture into brand material carrier easy for the public to accept, shows regional music culture by concrete forms of courses, to make contents of inheritance institutionalized and realize concrete and ordered implementation in music education and teaching.

\section{B. Reform Teaching Model and Teaching Method and Make Inheritance Path Diversified}

Looking from the past teaching model of college music, most teachers are inclined to one-way infuse-teaching style. Obviously, this teaching model has been unable to meet requirements for cultivation of applied talents. Teachers only teach students to sing a few local folk songs in class to finish teaching task of regional music culture, which cannot arouse students' interest in learning. As a local culture, regional music not only needs students to know about music, but also requires them to finish internalization of knowledge and real experience of cultural emotion through ways such as discussion, group cooperation research, case analysis, view and emulation as well as classroom simulation. It can make students deeply understand cultural background related to regional music, specific humanistic connotation and historical origin through teachers' instruction and discussion as well as exchange between groups under rich and innovative teaching model of regional music culture; only by letting students learn special dialects through group cooperation and apply music for voices with regional characteristics can we truly achieve the purpose of training students' basic quality in collecting folk songs and their skills of language communication and practical operating abilities in speaking and performance.

Besides, in order to improve diversification of inheritance path of regional music culture, universities shall break the barriers of teaching and research offices and let them collaborate and jointly create brand courses of regional music, such as collection of regional music culture, adaptation, performance, stage art and clothing; perform through classroom, artistic practice on campus, stage art practice and competition. On this basis, require students to participate in practical activities including art planning, publicizing and reporting of activities and performance, reflect on these activities through cases of curriculum integration and discussion, and finish evaluation on courses through various methods of assessment such as oral examination, thesis, report, comment and performance. In addition, teachers can also require students to research regional music culture according to regional culture favored by them, such as research a song, music and local drama of their hometown and show it through simulating classroom teaching, singing, instruction, group discussion, cooperative research and make percussion instruments. What's more, universities can make the best of multimedia such as internet with fast propagation speed and extensive range to construct online class and then complete the task of inheriting regional music culture. Lastly, teachers can use teaching model of inside and outside unification and take the idea of "walking out" and "inviting in" as guidance, effectively integrate government and folk inheritance way and further achieve the purpose of inheriting regional music culture. Teachers shall pay attention to practice platform of regional music culture, seize the opportunity to lead students to walk out of the classroom and the campus, face to face communicate, view and emulate and participate in folk activities such as art festival of folk culture and strengthen students' sense of identity and sense of pride for local culture then ensure the improvement of protection and inheritance consciousness. In addition, teachers shall make teaching methods diversified, such as expand teaching methods from individual classes in piano room and collective teaching in fixed classrooms to performance classes on stages; organize students to collect folk songs; lead students to go to museums to view and emulate and carry out artistic practice in theater and house of culture; participate in, organize and plan in festivals and folk activities. 


\section{Aggregation Force of "Teaching, Research and Performance" and Make Inheritance Patterns Three- Dimensional}

Although college music belongs to art discipline, in reality, music teaching and music scientific research have relationship of supplementing each other. In order to improve comprehensive quality of modern artistic talents, universities shall center on students, actively advocate teaching attitude with scientific research as the core and stimulate students under the guidance of teachers to participate in scientific research activities of regional music culture with continuous enthusiasm, integrate and carry forward good ethos of scientific research in the whole process of music teaching, integrate teaching, scientific research and artistic practice activities and strive to turn them into achievements. In the teaching process of promoting integration of art, science and practice, teachers can promote the level of aggregation force of "teaching, research and performance", carry out series of activities related to regional music culture through cooperation to achieve teaching goals. Firstly, "teaching" means that teachers shall first pay attention to teaching in the process of carrying out teaching activities of music culture and ensure students have basic cognition on characteristics, structure and rules of regional music culture; secondly, "research" means teachers and students under the leadership of teachers actively participate in research on regional music culture; "performance" means teachers complete practical tasks in teaching through providing platform for students and ensure students succeed in a special field of study and apply their knowledge. All in all, it is the mainstream way to develop regional music culture at the present stage through improving the level of aggregation force of "teaching, research and performance" and establishing three-dimensional inheritance pattern.

\section{CONCLUSION}

To sum up, local colleges shall fully promote integration of school and regional characteristics and carry out teaching and research as well as practical activities on the basis that teachers and students make concerted efforts and reach an agreement, use comprehensive, humanized and innovative teaching model to improve the level of music education, so that they can truly boost the development process of college music. All in all, teaching reform shall start the design and put it into practice from the top layer and fight for maximum support of policies and capitals to furthest promote the inheritance and development of regional music culture and truly complete current tasks of education and teaching reforms and development of artistic practice.

\section{REFERENCES}

[1] Xu Guimin. Application of Regional Music Culture in Public Course Teaching of College Music [J], Northern Music, 2014 (18): 172

[2] Chen Jia. Discussion on Regional Music Culture Teaching in College Music Public Course [J], Journal of Longyan University, 2014(02): 103107

[3] Yin Na. Humble Opinion on Regional Music Culture Teaching in College Music Public Course [J], Music Space Time, 2014(20): 143
[4] Huang Hui, Ma Da. Base on Regional Music Culture Research and Pay Attention to Traditional Music Education in Universities-Summary on "the Third National Universities Regional Music Culture Research Seminar" [J], China Music Education, 2014(03): 40-44

[5] Tan Liping, Ma Da. Focus on Regional Music Culture Research and Promote Music Geography Theory Construction-Summary on "the Third National Universities Regional Music Culture Research Seminar" [J], Journal of Xinghai Conservatory of Music, 2014 (02): 163-168

[6] Wang Jing. Research on Regional Music in the View of Ethnomusicology [J], Notonly Music, 2014 (03): 135

[7] Hou Xinlan. Exploration on Regional Music Culture Inheritance in Local College Music Education-Take Hunan Institute of Science and Technology as an Example [J], Music Creation, 2015 (10): 185-187

[8] Ke Shuguang. Analysis on Regional Music in View of Ethnomusicology [J], Yellow River of the Song, 2014 (08) 